\title{
Adsorption of Paracetamol in Hospital Wastewater Through Activated Carbon Filters
}

\author{
Antonio Macías-García ${ }^{1}$, Justo García-Sanz-Calcedo ${ }^{2, *(0)}$, Juan Pablo Carrasco-Amador ${ }^{2}$ (I) \\ and Raúl Segura-Cruz ${ }^{3}$ \\ 1 Department of Mechanical, Energetic and Materials Engineering, University of Extremadura, Elvas Avenue \\ s/n, 06006 Badajoz, Spain; amacgar@unex.es \\ 2 Department of Graphic Expression, University of Extremadura, Elvas Avenue s/n, 06006 Badajoz, Spain; \\ jpcarrasco@unex.es \\ 3 Rase Productive Project, Autonomous University of the State of Mexico, Saturno Street 207, 52159 Metepec, \\ Mexico; rase.proyectos@yahoo.com \\ * Correspondence: jgsanz@unex.es
}

Received: 23 March 2019; Accepted: 7 May 2019; Published: 10 May 2019

check for updates

\begin{abstract}
In recent years, pharmaceutical products have been causing a serious environmental problem in hospital wastewater and water purification plants. The elimination of these pollutants is difficult due to their resistance to biological degradation. Paracetamol has been detected in higher concentrations in hospital wastewater than in other buildings. Activated carbons are a good material for removing paracetamol from hospital wastewater. One of the starting materials to obtain activated carbons is kenaf, which is an easy plant to cultivate. To study the elimination of paracetamol from hospital wastewater by activated carbon, the textural and chemical characterization of activated carbon, as well as the kinetic study and the analysis of the paracetamol adsorption mechanism by the adsorbent, have been carried out. The activated carbon samples studied are micro-mesoporous, with high specific surface values. The chemical composition with presence of oxygen groups favours the adsorption process. The adsorption kinetics were adjusted to a pseudo-second order model. The adsorption mechanism followed the intraparticular diffusion model, carried out in two stages: a fast first stage on the surface of the adsorbent and a slow one inside the pore. Based on the kinetic study, the use of this type of carbon is a good application for the removal of paracetamol from hospital wastewater.
\end{abstract}

Keywords: wastewater hospital; healthcare engineering; healthcare projects

\section{Introduction}

Hospital wastewater includes a great diversity of micropollutants as a result of research, diagnosis, laboratories, and patients' excretions. The chemical substances that usually appear in these wastewater include drugs and their active principles, therapeutic drugs and their metabolites, disinfectants, X-ray contrast agents, halogenated solvents, heavy metals, etc. These wastewaters are usually discharged with high contamination level of pharmaceuticals without pre-treatment into sewerage networks and joined with urban wastewater with a wide variety of chemicals to be treated together in wastewater treatment plants. Pharmaceutical products are environmental pollutants that have been increasingly and extensively used during the last few decades [1]. The conventional wastewater treatment is not designed for the elimination of these compounds, so the treatment of these waters at source may be the most suitable way of eliminating these organic micro-contaminants, avoiding its dilution and favouring the possible separation and elimination of these compounds, thereby reducing the spread of diseases [2]. 
Contaminants from wastewater treatment plants are mainly human and veterinary pharmaceuticals, personal care products, surfactants, pesticides and various industrial additives. The removal of these contaminants in wastewater treatment plants is quite low since most of them are resistant to biological degradation [3].

Due to the potential risks to human healthcare, the presence of pharmaceuticals products at very low concentrations has raised concern in different sectors [4-6]. The presence of paracetamol in very low concentrations in water and wastewater has been detected, however, much higher concentrations have been measured in the effluents of hospitals [7-9].

Several methods have been studied in order to remove pharmaceuticals from wastewater, such as membrane bioreactors [10], conventional activated sludges [11], moving bed biofilm reactors [12] and activated carbons. Lignocellulosic materials are widely used as a starting material for activated carbon production. The kenaf is a plant of easy growth, that can reach up to $4 \mathrm{~m}$ high and has been used to obtain activated carbons.

Activated carbons are well known adsorbents in different fields, with environmental applications such as the adsorption of ions in dissolution or to mitigate gas emissions, [13-17] and are used clinically to treat accidental or deliberate drug overdoses, etc. [18-24].

Activated carbon is an adsorbent used to remove pollutants because of its properties, such as specific surface, pore volume, surface chemical groups and regeneration possibility, among others. In the bibliography there are excellent studies of carbon materials used to remove pharmaceutical pollutants, which is financially an attractive alternative for wastewater treatment [25,26].

The drug adsorption depends on the characteristics of the carbon (surface, pore size distribution and surface chemistry), from the drug (molecular size) and from the solution (temperature, $\mathrm{pH}$ and concentration) [27].

The aim of this paper is to analyse the kinetics of retention of paracetamol present in wastewater, both from hospitals and treatment plants, through activated carbons prepared from kenaf.

\section{Materials and Methods}

The material used was kenaf (K), from which activated carbon (AC) was prepared by chemical activation. Twenty-five $\mathrm{g}$ of kenaf were impregnated with $100 \mathrm{~mL} \mathrm{H}_{3} \mathrm{PO}_{4}$ (at concentrations of $36 \%$ (K-36-500), 60\% (K-60-500) and 85\% (K-85-500)) at $85^{\circ} \mathrm{C}$ for $2 \mathrm{~h}$. The solid product was subjected to a heat treatment at a temperature of $500{ }^{\circ} \mathrm{C}$, with a heating rate of $5{ }^{\circ} \mathrm{C} \mathrm{min}^{-1}$ in a $\mathrm{N}_{2}$ atmosphere (flow rate of $\left.85 \mathrm{~mL} \cdot \mathrm{min}^{-1}\right)$. Isothermal conditions at selected temperature were maintained for $2 \mathrm{~h}$. Finally, the product was washed using distilled water $(7 \mathrm{pH})$ and dried at $120^{\circ} \mathrm{C}$.

Chemical characterization was performed using surface functional group analysis by Fourier Transform Infrared (FT-IR) spectroscopy, with a Perkin Elmer model 1720 spectrometer, between 400 and $4000 \mathrm{~cm}^{-1}$.

Texture characterization of the samples was performed by nitrogen adsorption and mercury porosimetry. Nitrogen adsorption was carried out with Quantachrome Aurosorb-1 equipment and through the nitrogen adsorption isotherms obtained, the specific surface, micro and mesoporous volumes were determined. Mercury porosimetry (Quantachrome equipment) was used to measure the meso and macroporosity of activated carbons by applying controlled pressure to a sample immersed in mercury.

Paracetamol (N-(4-hydroxyphenyl) ethanamide), Aldrich (98\% purity) were used as adsorbate. Ultrapure water (milli-Q water purification systems) was used to prepare the paracetamol solutions. The $\mathrm{pH}$ of the solutions used in kinetics and equilibrium tests was 5.9 at the beginning.

Approximately an amount of $10 \mathrm{mg}$ of sample was first placed in vessels provided with screw-up caps in the kinetic experiments. Then, $15 \mathrm{~mL}$ of paracetamol $120 \mathrm{mg} \cdot \mathrm{L}^{-1}$ aqueous solution was added. Next, the vessels were placed in a Selecta thermostatic bath containing water at $25^{\circ} \mathrm{C}$. Both the liquid and solid phases were maintained under continuous agitation of 50 oscillations $\mathrm{min}^{-1}$, at different 
times ranging between $5 \mathrm{~min}$ and $360 \mathrm{~h}$. By this experimental procedure, apparent adsorption rates were determined.

Different kinetic models were tested: pseudo-first order model, pseudo-second order model, and intraparticle diffusion model. The pseudo-first order equation-also known as Lagergren equation-is expressed as:

$$
\frac{d q_{t}}{d t}=k_{1}\left(q_{e}-q_{t}\right)
$$

where $k_{1}$ represents the adsorption rate constant $\left(\mathrm{min}^{-1}\right), q_{e}$ and $q_{t}$ the amounts of paracetamol adsorbed $(\mathrm{mg} / \mathrm{g})$ at equilibrium and $t$ the time (min). Equation (1) may be integrated as:

$$
\log \left(q_{e}-q_{t}\right)=\log q_{e}-\frac{k_{1}}{2.303} t
$$

In consequence, a plot of $\log \left(q_{e}-q_{t}\right)$ versus $t$ should give rise to a straight line, if the kinetic data fit to the pseudo-first order model. The interception and slope of this line can be easily used to determine the values of $k_{1}$ and $q_{e}$.

The pseudo second-order kinetic model of Blanchard et al. [28] was proposed in 1980. Ho and MacKay 1995 published a modified version later [29]. The mathematical expression of this model is:

$$
\frac{d q_{t}}{d t}=k_{2}\left(q_{e}-q_{t}\right)^{2}
$$

where $k_{2}$ represents the adsorption rate constant of pseudo-second order model, expressed in $\mathrm{g} / \mathrm{mg}$ min. This is shown in Equation (4).

$$
\frac{t}{q_{t}}=\frac{1}{k_{2} q_{e}^{2}}+\frac{1}{q_{e}} t
$$

Analogously, if the kinetic data fit to the pseudo-second order model, a plot of $t / q$ versus $t$ should give rise to a straight line, and this can be easily used to determine the values of $q_{e}$ (slope) and $k_{2}$ (intercept).

The intraparticle diffusion model was proposed by Weber and Morris in 1962. They characterized the dependency between the square root of the time and the specific adsorption, where the slope represents the speed of the intraparticle diffusion [30]. Equation (5) defines the previous diffusion:

$$
q_{t}=k_{i d} t_{e}^{\frac{1}{2}}+C
$$

where $k_{i d}$ represents the intraparticle diffusion rate constant, expressed in $\mathrm{mg} / \mathrm{g} \min ^{1 / 2}$ and $C$ is a constant indicating the thickness of the boundary layer surrounding the adsorbent, expressed in $\mathrm{mg} / \mathrm{g}$. If the value of $C$ is high, significant boundary layer effects are expected. That is, it may be assumed that the adsorption process is mostly controlled by intraparticle diffusion, as long as the $q_{t}$ versus $t^{1 / 2}$ plot provides a straight line passing through the origin (i.e., with a value of $C=0$ ). On the other hand, if $q_{t}$ versus $t^{1 / 2}$ plot exhibits more than one single linear plot, then we may deduce that the adsorption process follows two or more steps.

\section{Results and Discussions}

In the adsorption process by activated carbon a porous texture is required whose pore width is greater than the size of the drug molecule.

\subsection{Textural Characterization}

The adsorption capacity of carbonaceous materials is related to chemical and textural characteristics. Therefore, the presence of a well-developed pore distribution (i.e., mesopores) is very important. Also, the size of the micropores should be large enough to accommodate the adsorbate molecule. 
Table 1 shows the values of the textural parameters. These values were obtained from the adsorption isotherms of $\mathrm{N}_{2}$ at $-196^{\circ} \mathrm{C}\left(\mathrm{S}_{\mathrm{BET}}\right.$, specific surface, $\mathrm{V}_{\mathrm{mi}}$, micropore volume, $\mathrm{V}_{\mathrm{me}}$, mesopore volume) and the curves of the accumulated pore volume versus the pore radius (mercury porosimetry, $\mathrm{V}_{\text {me-p}}$, wide mesopore volume, $\mathrm{V}_{\text {ma-p }}$, wide macropore volume).

Table 1. Textural parameters of activated carbons (ACs) prepared with $\mathrm{H}_{3} \mathrm{PO}_{4}$.

\begin{tabular}{|c|c|c|c|c|c|}
\hline Sample & $\begin{array}{c}S_{B E T} \\
\left(m^{2} \cdot g^{-1}\right)\end{array}$ & $\begin{array}{c}V_{\mathrm{mi}} \\
\left(\mathrm{cm}^{3} \cdot \mathrm{g}^{-1}\right)\end{array}$ & $\begin{array}{c}V_{\text {me }} \\
\left(\mathrm{cm}^{3} \cdot \mathrm{g}^{-1}\right)\end{array}$ & $\begin{array}{c}V_{\text {me-p }} \\
\left(\mathrm{cm}^{3} \cdot \mathrm{g}^{-1}\right)\end{array}$ & $\begin{array}{c}V_{\text {ma-p }} \\
\left(\mathrm{cm}^{3} \cdot \mathrm{g}^{-1}\right)\end{array}$ \\
\hline K-36-500 & 1556 & 0.88 & 0.22 & 0.22 & 0.25 \\
\hline K-60-500 & 2270 & 0.88 & 1.15 & 0.35 & 0.42 \\
\hline K-85-500 & 1957 & 1.11 & 0.96 & 0.96 & 0.59 \\
\hline
\end{tabular}

The highest values of pore volume and surface area correspond to the AC samples, prepared using phosphoric acid solutions, with concentrations $(60 \%$ and $85 \%)$ and temperature $\left(500{ }^{\circ} \mathrm{C}\right)$. The development of porosity, which results from carbonisation of the starting material at a temperature of $500{ }^{\circ} \mathrm{C}$ by activation with $\mathrm{H}_{3} \mathrm{PO}_{4}$, is related to the fact that the phosphorus species present in the impregnated product tend to pass into the gas phase, resulting in a product structural expansion [31].

\subsection{Chemical Characterization}

Regarding the analysis of surface functional groups, the FT-IR spectra obtained for samples showed three very wide bands with maximum absorption peaks located at 3400, 1600 and $1200 \mathrm{~cm}^{-1}$.

At $3400 \mathrm{~cm}^{-1}$ the band associated with $\mathrm{O}-\mathrm{H}$ stretching vibrations in alcohols and carboxylic acids is located. It should be noted that the intensity of this band in the samples is proportional to the concentration of acid groups found for each of them.

The band at $1600 \mathrm{~cm}^{-1}$ is due to the presence of $\mathrm{C}=\mathrm{C}$ groups corresponding to aromatic rings.

In the spectrum region around $1200 \mathrm{~cm}^{-1}$, a vibration band is observed in the plane $=\mathrm{CH}$ of the aromatics $=\mathrm{CH}$ [32]. On the other hand, due to the tension vibration of the $\mathrm{P}-\mathrm{O}$ and $\mathrm{P}=\mathrm{O}$ bonds, spectral bands were registered at $1260-855 \mathrm{~cm}^{-1}$ and $1300-960 \mathrm{~cm}^{-1}$, respectively. For P-C bond, however, the band was located between $800-900 \mathrm{~cm}^{-1}$ [33].

Finally, the peak at $1710 \mathrm{~cm}^{-1}$ was easily visible in the spectra of these series (Figure 1).

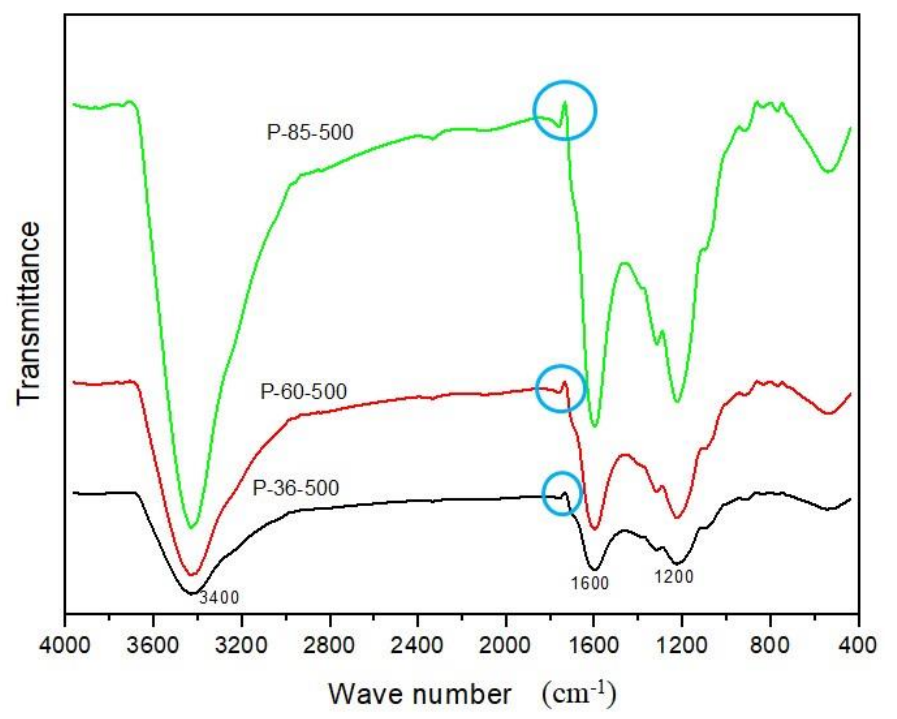

Figure 1. Fourier Transform Infrared (FT-IR) spectra for the samples. 


\subsection{Kinetic Study}

The study of the contact time for the removal of paracetamol by activated carbons prepared from kenaf in Figure 2, shows rapid adsorption by different types of carbon in the first 300 minutes. Then, the carbons slowly adsorb the adsorbate until equilibrium is reached. The K-60-500 sample reaches the maximum adsorption of paracetamol. This fact may be related to the higher values of the $S_{\mathrm{BET}}$ specific surface. In the bibliography, several kinetics models have been proposed for the study of the mechanism by which drugs may be adsorbed [34-36].

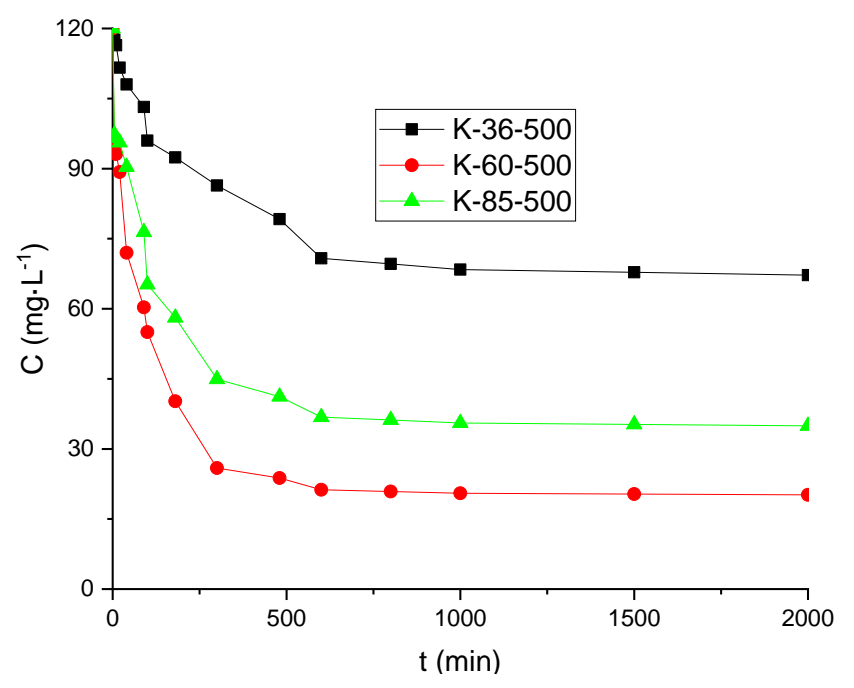

Figure 2. Adsorption kinetics of the prepared samples.

Table 2 shows the kinetic parameters of the prepared samples.

Table 2. Kinetic parameters.

\begin{tabular}{ccc}
\hline Samples & $\boldsymbol{q}_{\boldsymbol{e}} \mathbf{( \mathbf { m g } \cdot \mathrm { L } ^ { - \mathbf { 1 } } )}$ & $\boldsymbol{t}_{\text {equilibrium }}$ (min) \\
\hline $\mathrm{K}-36-500$ & 0.08 & 1500 \\
$\mathrm{~K}-60-500$ & 0.15 & 1000 \\
$\mathrm{~K}-85-500$ & 0.13 & 1000 \\
\hline
\end{tabular}

In this work, to investigate the mechanism of paracetamol adsorption, three kinetic models are selected: pseudo first-order, pseudo second-order and intraparticle diffusion.

\subsubsection{Pseudo-First Order Kinetic Model}

The experimental data were adjusted to the pseudo-first order kinetic model. Figure 3 shows the values of $\log \left(q_{e}-q_{t}\right)$ obtained from the kinetic data. From slope and intercept of this plot, the plots of $\log \left(q_{e}-q_{t}\right)$ versus $t$ for the pseudo first-order model, the $k_{1}$ and $q_{e}$ values were calculated. Table 3 shows $k_{1}$ values, $q_{e}$ calculated and $\mathrm{R}^{2}$ ranging from 0.933 to 0.786 (low).

Table 3. Parameters of the kinetic models.

\begin{tabular}{ccccccc}
\hline \multirow{2}{*}{ Samples } & \multicolumn{3}{c}{ Intraparticle Diffusion } & \multicolumn{3}{c}{ Intraparticle Diffusion } \\
\cline { 2 - 7 } & $\boldsymbol{q}_{\boldsymbol{e}} \mathbf{( \mathbf { m g } / \mathbf { g } )}$ & $\boldsymbol{k}_{\mathbf{1}} \mathbf{( g / \mathbf { m g } / \mathbf { m i n } )}$ & $\mathbf{R}^{\mathbf{2}}$ & $\boldsymbol{q}_{\boldsymbol{e}}(\mathbf{m g} / \mathbf{g})$ & $\boldsymbol{k}_{\mathbf{2}}\left(\mathbf{m i n}^{\mathbf{1}}\right)$ & $\mathbf{R}^{\mathbf{2}}$ \\
\hline $\mathrm{K}-36-500$ & 0.060 & 0.0025 & 0.933 & 0.086 & 0.0750 & 0.996 \\
$\mathrm{~K}-60-500$ & 0.062 & 0.0035 & 0.857 & 0.154 & 0.1700 & 0.999 \\
$\mathrm{~K}-85-500$ & 0.061 & 0.0022 & 0.786 & 0.132 & 0.1440 & 0.999 \\
\hline
\end{tabular}




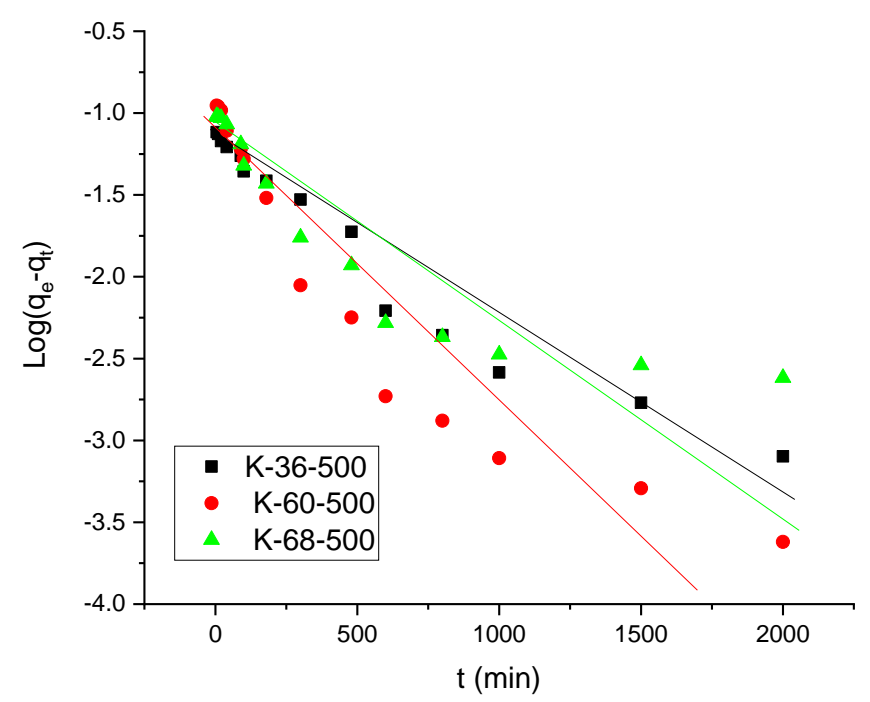

Figure 3. The pseudo first-order adsorption kinetics.

The $q_{e}$ experimental values obtained do not accord with those calculated in Table 3 . This indicate that the adsorption of paracetamol onto activated carbons is not a first-order reaction.

In some referenced literature, this model was not considered as optimal to adjust the data of adsorption kinetics on activated carbons [37-39].

\subsubsection{Pseudo-Second Order Kinetic Model}

The experimental data $t / q_{t}$ versus time $t$, from the kinetic model of pseudo-second order are represented in Figure 4, from the slope the value $q_{e}$ was obtained, while the intercept provided the value $k_{2}$. The kinetic parameters found in the adsorption process are collected in Table 3.

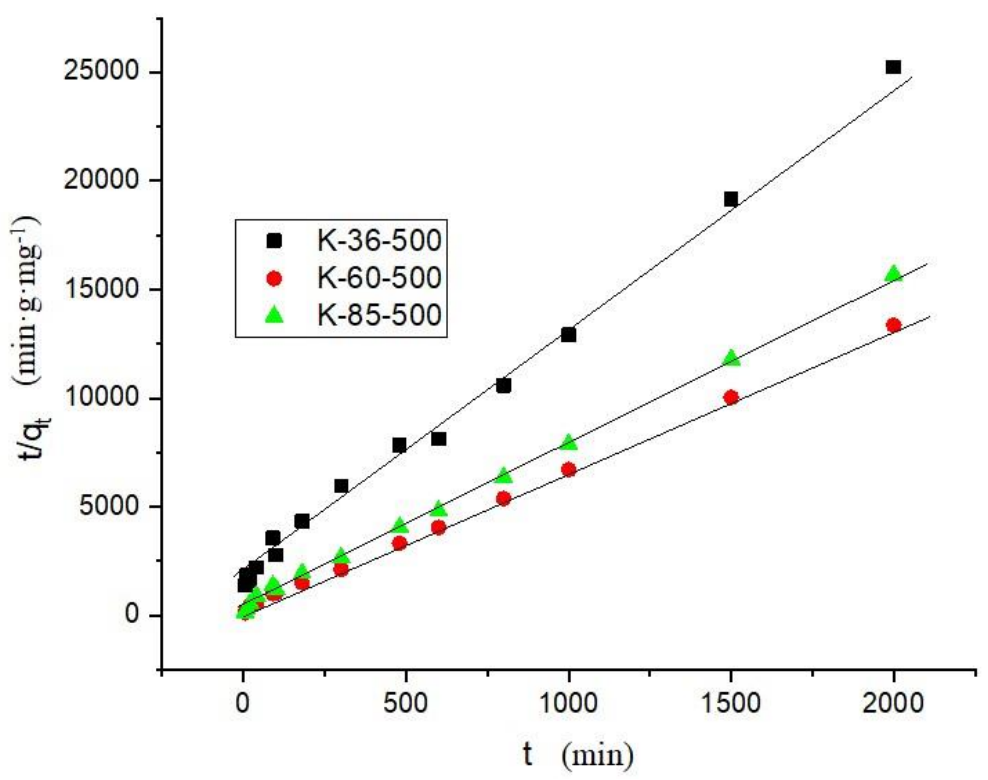

Figure 4. The pseudo second-order adsorption kinetics.

In the process of adsorption, the values $q_{e}$ and $k_{2}$ are very similar for K-60-500 and K-85-500 samples which is in perfect agreement with the presence of superficial groups and pore distribution. Also, the K-60-500 sample presents lower $q_{e}$ and $k_{2}$ values than the other samples. This may be due to the presence of a greater porous development that would favour the adsorption process. 
Table 4 shows that the $\mathrm{R}^{2}$ values are closer to 1 in adsorption of pseudo-second order than in adsorption kinetics of pseudo-first order. Consequently, the pseudo-second order model fits better than the first one. These results indicate that with their adsorption capacity, K-60-500 and K-85-500 could become an interesting economic alternative. Thus, it is possible to reduce the time required to reach equilibrium.

Table 4. Parameters of intraparticle diffusion kinetics.

\begin{tabular}{|c|c|c|c|c|c|c|}
\hline \multirow{2}{*}{ Samples } & \multicolumn{3}{|c|}{ Intraparticle Diffusion } & \multicolumn{3}{|c|}{ Intraparticle Diffusion } \\
\hline & $C_{1}(\mathrm{mg} / \mathrm{g})$ & $k_{i d 1}(\mathrm{~g} / \mathrm{mg} / \mathrm{min})$ & $\mathbf{R}^{2}$ & $C_{2}(\mathrm{mg} / \mathrm{g})$ & $k_{i d 2}\left(\min ^{-1}\right)$ & $\mathbf{R}^{2}$ \\
\hline K-36-500 & 0.0893 & 0.06035 & 0.988 & 0.0773 & 0.0044 & 0.981 \\
\hline K-60-500 & 0.1551 & 0.13868 & 0.971 & 0.1456 & 0.0133 & 0.943 \\
\hline K-85-500 & 0.1332 & 0.11790 & 0.956 & 0.1233 & 0.0103 & 0.933 \\
\hline
\end{tabular}

\subsubsection{Intraparticle Diffusion Kinetics}

The previous kinetic models do not identify the diffusion mechanism; therefore, in order to know how adsorption is performed, the intraparticle diffusion model based on the theory proposed by Weber and Morris was applied [40].

This model assumes that if the regression of $q_{t}$ vs. $t^{1 / 2}$ is linear and passes through the origin, intraparticle diffusion is the only rate-limiting step [41-43]. Nevertheless, the surface diffusion and equilibrium adsorption may also limit the velocity at different stages of the kinetic profile, which would result in a multi-linearity in the intraparticle diffusion plot [44].

To fit the data to the pseudo-first and pseudo-second order models, the linear expressions of the equations were used. Since some authors have warned of possible errors in the use of these equations [45], the adjustments have been made to the nonlinear pseudo-first and pseudo-second order models and the results discussed with them. The plot of $q_{t}$ versus $t^{1 / 2}$ for the adsorption process (Figure 5) shows two linear sections of paracetamol adsorption.

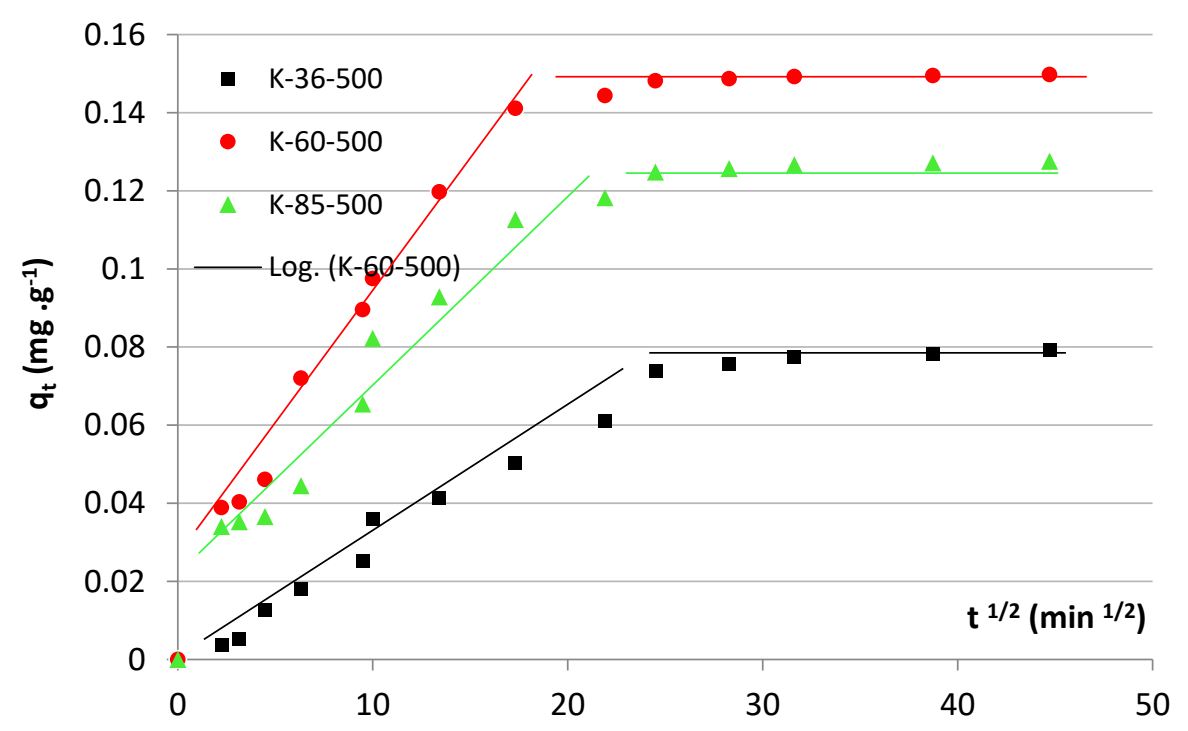

Figure 5. Intraparticle diffusion kinetics.

With respect to intraparticle diffusion plots, the first stage is due to instantaneous adsorption or adsorption on the outer surface, where the adsorbate travels to the outer surface of the adsorbent. A gradual adsorption takes place where the intraparticle diffusion is the velocity limiting in the second, i.e., the adsorbate travels within the pores of the adsorbent. In some cases, there is a third stage 
representing the final equilibrium where intraparticle diffusion begins to decrease due to the low adsorbate concentration; adsorption occurs within the adsorbent [46].

As shown in Figure 5, the first linear part, $\left(0-25 \mathrm{~min}^{-1}\right)$ indicates the adsorption period. This corresponds to transfer of external mass or paracetamol diffusion through the boundary layer of the adsorbent, where paracetamol distributes rapidly on the external surface of the activated carbon. This first stage is quite common in relation to the other adsorbents [47]. The second linear part indicates an adsorption period between 25 and $45 \mathrm{~min}^{-1}$. This period corresponds to the intraparticle diffusion and the union of paracetamol with the internal active sites of the activated carbons. Table 4 shows the values of $k_{i d i}, C_{i}$ and correlation coefficients $\left(\mathrm{R}^{2}\right)$.

Figure 5 shows two well defined stages, the first stage presents an instant adsorption of the adsorbate on the external adsorbent surface, which corresponds to higher values of $k_{i d 1}$ with respect to stage two $\left(k_{i d 1}>k_{i d 2}\right)$ and lower values of $C_{1}$, indicating that the thickness of the boundary layer is low. The adsorbate, as a velocity limiting stage, travels within the pores of the adsorbent, and corresponds to smaller values of $k_{i d 2}<k_{i d 1}$ velocity and values of the boundary layer thickness high $C_{2}>C_{1}$. It is possible to understand wastewater services consumer behavior, through which it may be possible to enhance ways of reducing environmental disturbances [48].

\section{Conclusions}

The samples prepared by chemical treatment have a porous development very related to the concentration of the activating agent $\mathrm{H}_{3} \mathrm{PO}_{4}$, which suggests that textural parameters $\left(\mathrm{S}_{\mathrm{BET}}\right.$ and porosity distribution) exerts a determining influence on the behavior of the samples in the process of retention of paracetamol.

The equilibrium time varies between $20 \mathrm{~min}$ and $2000 \mathrm{~min}$ in the adsorption process. The kinetics of these processes correspond to a pseudo-second order. The intraparticle diffusion model shows that kinetic mechanism presents two development stages. In the first stage, paracetamol diffuses through the adsorbent limiting layer; in the second one (intraparticle diffusion), the union of paracetamol with the active carbon sites takes place.

The K-60-500 sample has the highest paracetamol retention capacity, with a fast superficial adsorption mechanism in the first stage, and a slow second one, in the interior of the pore as consequence of the limiting layer in the surface of the adsorbent. Finally, the K-60-500 sample could be used as a filter to remove paracetamol from hospital wastewater.

The engineering, maintenance and preventive medicine services of each hospital must monitor the quality of the discharges, through periodic controls of the quality of their residual water. The preventive maintenance of the proposed carbon filters should be included in the hospital's maintenance plan, with the frequency of inspection recommended by the manufacturer. The cost of the filter is perfectly bearable by the hospital, and its amortisation is very rapid, as it contributes to reduce the environmental impact of the hospital, as well as its sustainability.

Author Contributions: Data curation, J.P.C.-A.; Formal analysis, A.M.-G.; Investigation, A.M.-G., J.G.-S.-C.; Methodology, A.M.-G.; Software, J.P.C.-A.; Supervision, J.G.-S.-C.; Visualization, R.S.-C.; Writing-original draft, A.M.-G.; Writing-review \& editing, J.G.-S.-C.

Acknowledgments: The authors wish to acknowledge to the Junta de Extremadura and the European Social Found (FEDER) for the support of this research work. This study has been carried out through the Research Project GR-18029 and GR-18164 linked to the VI Regional Plan for Research, Technological Development and Innovation from the General Government of Extremadura 2017-2020.

Conflicts of Interest: The authors declare no conflict of interest. 


\section{References}

1. Escher, B.I.; Baumgartner, R.; Koller, M.; Treyer, K.; Lienert, J.; McArdell, C.S. Environmental toxicology and risk assessment of pharmaceuticals from hospital wastewater. Water Res. 2011, 45, 75-92. [CrossRef]

2. Collivignarelli, M.C.; Abbà, A.; Benigna, I.; Sorlini, S.; Torretta, V. Overview of the Main Disinfection Processes for Wastewater and Drinking Water Treatment Plants. Sustainability 2018, 10, 86. [CrossRef]

3. Petrie, B.; Barden, R.; Kasprzyk-Hordern, B. A review on emerging contaminats in wastewaters and the environment: Current knowledge, understudied areas and recommendations for future monitoring. Water Res. 2015, 72, 3-27. [CrossRef] [PubMed]

4. Rossner, A.; Snyder, S.A.; Knappe, D.R.U. Removal of emerging contaminants of concern by alternative adsorbents. Water Res. 2009, 43, 3787-3796. [CrossRef] [PubMed]

5. De García, S.O.; Pinto, G.P.; Encina, P.G.; Mata, R.I. Consumption and occurrence of pharmaceutical and personal care products in the aquatic environment in Spain. Sci. Total Environ. 2013, 444, 451-465. [CrossRef] [PubMed]

6. Deo, R.P.; Halden, R.U. Pharmaceuticals in the built and natural water environment of the United States. Water 2013, 5, 1346-1365. [CrossRef]

7. Gómez-Chaparro, M.; García-Sanz-Calcedo, J.; Armenta-Márquez, L. Study on the Use and Consumption of Water in Spanish Private Hospitals as related to Healthcare Activity. Urban Water J. 2018, 15, 601-608. [CrossRef]

8. Al Sawaf, M.B.; Karaca, F. Different stakeholders' opinions toward the sustainability of common textile wastewater treatment technologies in Turkey: A Case study Istanbul province. Sustain. Cities Soc. 2018, 42, 194-205. [CrossRef]

9. González, A.G.; García-Sanz-Calcedo, J.; Salgado, D.R. Quantitative Determination of Potable Cold Water Consumption in German Hospitals. Sustainability 2018, 10, 932. [CrossRef]

10. Kovalova, L.; Siegrist, H.; Singer, H.; Wittmer, A.; McArdell, C. Hospital wastewater treatment by membrane bioreactor: Performance and efficiency for organic micropollutant elimination. Environ. Sci. Technol. 2012, 46, 1536-1545. [CrossRef] [PubMed]

11. Thiebault, T.; Boussafir, M.; Le Milbeau, C. Occurrence and removal efficiency of pharmaceuticals in an urban wastewater treatment plant: Mass balance, fate and consumption assessment. J. Environ. Chem. Eng. 2017, 5, 2894-2902. [CrossRef]

12. Escola Casas, M.; Chhetri, R.K.; Ooi, G.; Hansen, K.M.S.; Litty, K.; Christensson, M.; Kragelund, C.; Andersen, H.R.; Bester, K. Biodegradation of pharmaceuticals in hospital wastewater by staged moving bed biofilm reactors. Water Res. 2015, 83, 293-302. [CrossRef]

13. Macías-García, A.; Corzo, M.G.; Domínguez, M.A.; Franco, M.A.; Naharro, J.M. Study of the adsorption and electro-adsorption process of $\mathrm{Cu}$ (II) ions within thermally and chemically modified activated carbon. J. Hazard. Mater. 2017, 328, 46-55. [CrossRef] [PubMed]

14. Mokhtari, P.; Ghaedi, M.; Dashtian, M.R.; Rahimi, M.R.; Purkait, M.K. Removal of methyl orange by copper sulphide nanoparticles loaded activated carbon kinetic and isotherm investigation. J. Mol. Liq. 2016, 219, 299-305. [CrossRef]

15. Zhou, Q.; Duan, Y.F.; Hong, Y.G.; Zhu, C.; She, M.; Zhang, J.; Wei, H.Q. Experimental and kinetic studies of gas-phase mercury adsorption by ram and bromide modified activated carbon. Fuel Process. Technol. 2015, 134, 325-332. [CrossRef]

16. Nekonei, F.; Nekonei, S.; Tyagi, I.; Gupta, V.K. Kinetic, thermodynamic and isotherm studies for acid blue 129 removal liquids using copper oxide nanoparticle-modified activated carbon as a novel adsorbent. J. Mol. Liq. 2015, 201, 124-133. [CrossRef]

17. Krishnan, K.A.; Anirudhan, T.S. Removal of cadmium (II) from aqueous solutions by steam-activated sulphurised carbon prepared from sugar-bagasse pith: Kinetics and equilibrium studies. Water Sa 2003, 29, 147-156. [CrossRef]

18. Pezoti, O.; Cazetta, A.L.; Bedin, K.C.; Souza, L.S.; Martins, A.C.; Silva, T.L.; Junior, O.O.S.; Visentainer, J.V.; Almeida, V.C. NaOH-activated carbon of high surface area produced from guava seeds as a high-efficiency adsorbent for amoxicillin removal: Kinetic, isotherm and thermodynamic studies. Chem. Eng. J. 2016, 288, 778-788. [CrossRef] 
19. Yu, F.; Li, Y.; Han, S.; Ma, J. Adsorptive removal of antibiotics from aqueous solution using carbon materials. Chemosphere 2016, 153, 365-385. [CrossRef]

20. Nielsen, L.; Biggs, M.J.; Skinner, W.; Bandosz, T.J. The effects of activated carbon surface features on the reactive adsorption of carbamazepine and sulfamethoxazole. Carbon 2014, 80, 419-432. [CrossRef]

21. Li, H.; Zhang, D.; Han, X.; Xing, B. Adsorption of antibiotic ciprofloxacin on carbon nanotubes: $\mathrm{pH}$ dependence and thermodynamics. Chemosphere 2014, 95, 150-155. [CrossRef]

22. Álvarez-Torrellas, S.; Rodríguez, A.; Ovejero, G.; García, J. Comparative adsorption performance of ibuprofen and tetracycline from aqueous solution by carbonaceous materials. Chem. Eng. J. 2016, 283, 936-947. [CrossRef]

23. Ersan, G.; Kaya, Y.; Apul, O.G.; Karanfil, T. Adsorption of organic contaminants by graphene nanosheets, carbon nanotubes and granular activated carbons under natural organic matter preloading conditions. Sci. Total Environ. 2016, 565, 811-817. [CrossRef]

24. Rakic, V.; Rac, V.; Krmar, M.; Otman, O.; Auroux, A. The adsorption of pharmaceutically active compounds from aqueous solutions onto activated carbons. J. Hazard. Mater. 2015, 282, 141-149. [CrossRef]

25. Altmann, J.; Sperlich, A.; Jekel, M. Integrating organic micropolluant removal into tertiary filtration: Combining PAC adsorption with advances phosphosrus removal. Water Res. 2015, 84, 58-65. [CrossRef]

26. Altmann, J.; Rehfeld, D.; Träder, K.; Sperlich, A.; Jekel, M. Combination of granular activated carbon adsorption and deep-bed filtration as a single advanced wastewater treatment step for organic micropolluant and phosphorus removal. Water Res. 2016, 92, 131-139. [CrossRef]

27. Radovic, L.R.; Moreno-Castilla, C.; Rivera-Utrilla, J. Carbon materials as adsorbents in aqueous solutions. Chem. Phys. Carbon 2001, 27, 227-406.

28. Blanchard, G.; Maunaye, M.; Martin, G. Removal of Heavy Metals from Waters by Means of Natural Zeolites. Water Res. 1984, 18, 1501. [CrossRef]

29. Ho, Y.S.; McKay, G. A Comparison of Chemisorption Kinetic Models Applied to Pollutant Removal on Various Sorbents. Process Saf. Environ. Prot. 1998, 76, 332. [CrossRef]

30. Weber, W.J.; Morris, J.C. Advances in water pollution research: Removal of biologically resistant pollutant from wastewater by adsorption. In Proceedings of the 1st International Conference on Water Pollution Symposium, Oxford, UK, 1 September 1962; pp. 231-266.

31. Olivares-Marín, M.; Fernández-González, C.; García, A.M.; Gómez-Serrano, V. Porous structure of activated carbon prepared from cherry stones by chemical activation with phosphoric acid. Energy Fuels 2007, 21, 2942-2949. [CrossRef]

32. Karen, J.; Peña, H.; Giraldo, L.; Moreno, J.C. Preparation of activated carbon from orange peel by chemical activation. Physical and chemical characterization. Rev. Colomb. Quím. 2012, 41, 311-323.

33. Pretsch, W.; Clerc, E.; Seibl, T.; Simon, J. Tabla Para la Elucidación Estructural de Compuestos Orgánicos por Métodos de Espectroscópicos; Alambra: Madrid, Spain, 1980.

34. Melillo, M.; Phillips, G.J.; Davies, J.G.; Lloyd, A.W.; Tennison, S.R.; Kozynchenko, O.P.; Mikhalovsky, S.V. The effect of protein binding on ibuprofen adsorption to activated carbons. Carbon 2004, 42, 565-571. [CrossRef]

35. Otero, M.A.; Grande, C.A.; Rodrigues, E. Adsorption of salicylic acid onto polymeric adsorbents and activated charcoal. React. Funct. Polym. 2004, 60, 203-213. [CrossRef]

36. Bridelli, M.G.; Ciati, A.; Crippa, P.R. Binding of chemicals to melanins re-examined: Adsorption of some drugs to the surface melanin particles. Biophys. Chem. 2006, 119, 137-145. [CrossRef]

37. Ruiz, B.; Cabrita, I.; Mestre, A.S.; Parra, J.B.; Pires, J.; Carvalho, A.P.; Ania, C.O. Surface heterogeneity effects of activated carbons on the kinetics of paracetamol removal from aqueoussolution. Appl. Surf. Sci. 2010, 256, 5171-5175. [CrossRef]

38. Wen, D.; Ho, Y.S.; Tang, X. Comparative sorption kinetic studies of ammonium onto zeolite. J. Hazard. Mater. 2006, 133, 252-256. [CrossRef]

39. Mukoko, T.; Mupa, M.; Guyo, U.; Dziike, F. Preparation of Rice Hull Activated Carbon for the Removal of Selected Pharmaceutical Waste Compounds in Hospital Effluent. J. Environ. Anal. Toxicol. 2015, 7, 2-9.

40. Weber, W.J.; Morris, J.C. Kinetics of adsorption on carbon from solutions. J. Sanit. Eng. Div. Am. Soc. Civ. Eng. 1963, 89, 31-60. 
41. Asuquo, E.; Martin, A.; Nzerem, P.; Siperstein, F.; Fan, X. Adsorption of $\mathrm{Cd}(\mathrm{II})$ and $\mathrm{Pb}(\mathrm{II})$ ions from aqueous solutions using mesoporous activated carbon adsorbent: Equilibrium, kinetics and characterisation studies. J. Environ. Chem. Eng. 2017, 5, 679-698. [CrossRef]

42. Mittal, A.; Malviya, A.; Kaur, D.; Mittal, J.; Kurup, L. Studies on the adsorption kinetics and isotherms for the removal and recovery of Methyl Orange from wastewaters using waste materials. J. Hazard. Mater. 2007, 148, 229-240. [CrossRef]

43. Huang, Y.; Li, S.; Chen, J.; Zhang, X.; Chen, Y. Adsorption of Pb(II) on mesoporous activated carbons

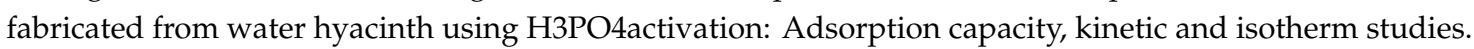
Appl. Surf. Sci. 2014, 293, 160-168. [CrossRef]

44. Qiu, H.; Lv, L.; Pan, B.C.; Zhang, Q.J.; Zhang, W.M.; Zhang, Q.X. Critical review in adsorption kinetic models. J. Zhejiang Univ. A 2009, 10, 716-724. [CrossRef]

45. Kumar, K.V. Linear and non-linear regression analysis for the sorption kinetics of methylene blue onto activated carbon. J. Hazard. Mater. 2006, 137, 1538-1544. [CrossRef]

46. Hameed, B.H.; Tan, I.A.W.; Ahmad, A.L. Adsorption isotherm, kinetic modelling and mechanism of 2,4,6-trichlorophenol on coconut husk-based activated carbon. Chem. Eng. J. 2008, 144, 235-244. [CrossRef]

47. Carabineiro, S.A.C.; Thavorn-Amornsri, T.; Pereira, M.F.R.; Figueiredo, J.L. Adsorption of ciprofloxacin on surface-modified carbon Materials. Water Res. 2011, 45, 4583-4591. [CrossRef]

48. Petrescu, D.C.; Petrescu-Mag, R.M.; Manciula, D.I.; Nistor, I.A.; Ilies, V.I. Wastewater Reflections in Consumer Mind: Evidence from Sewage Services Consumer Behaviour. Sustainability 2019, 11, 123. [CrossRef]

(C) 2019 by the authors. Licensee MDPI, Basel, Switzerland. This article is an open access article distributed under the terms and conditions of the Creative Commons Attribution (CC BY) license (http://creativecommons.org/licenses/by/4.0/). 